\title{
A csehszlovák állam születése: Prága, 1918. október 28.
}

\author{
Andrej Tóth*
}

\begin{abstract}
The birth of the Czechoslovakian state: Prague, October 28, 1918. There was no Czechoslovakian state at the outbreak of WW1. Apart from a few „dreaming emigrants“, no one thought in 1914 that such a state would ever come into existence. However, the Great War (1914-1918) enabled the birth of the Czechoslovakian state. On October 18, 1918, the national committee in Prague announced the foundation of the new state. Through the October 28 events in Prague and the decisions of Czech politicians, the paper presents the birth of the First Czechoslovakian Republic.
\end{abstract}

Keywords Great War (1914-1918), history of Central-Europe, birth of the First Czechoslovakian Republic, Prague

Csehszlovákia történelmének alapvető dátuma 1918. október 28., amikor a Nemzeti Bizottság kihirdette az új állam megalapítását. Az államforma meghatározása ekkor még függőbben maradt, erre csak később került sor, 1918. november 14-én, miután I. Károly november 11-én Ausztria irányában lemondott minden részvételről az államügyek vitelében. Bár a progresszív Szocialista Tanács ${ }^{1}$ ettől jóval korábban sürgette az önálló állam kihirdetését. A független csehszlovák állam kikiáltását már október 14-én követelte, amikor a Nemzeti Bizottság általános sztrájkot hirdetett és demonstrációkat hívott össze országszerte, tiltakozásul a cseh tartományokból való élelem elszállítása ellen. Az önálló állam kikiáltását azonban a konzervatív Nemzeti Bizottság ${ }^{2}$ még ekkor erélyesen elutasította, koordinált és meggondolt magatartásra

\footnotetext{
* Intézmény: University of Economics Prague

Email: andrej.toth@seznam.cz

${ }^{1}$ A Szocialista Tanács 1918. szeptember 6-án alakult meg a szociáldemokrata és a szocialista párt elnökségéinek közös ülésén. A Szocialista Tanács a szociális, gazdasági és belpolitikai kérdésekkel volt hivatott foglalkozni. Bár hivatalosan a Nemzeti Bizottság testületének számított, eleinte azonban inkább vetélytársaként szerepelt a Nemzeti Bizottsággal szemben. V. ö. Galandauer Jan 1988, 221-222.

${ }^{2}$ A politikai pártok erőviszonyai a Nemzeti Bizottságban, amely a hazai ellenállás központi szerve volt, 1918. július 13-án rendeződtek véglegesen. Az egyes politikai pártok a Nemzeti Bizottságban az 1911-es, a Birodalmi Tanácsba lezajlott választási eredmények alapján kaptak helyet. A legtöbb, összesen 10 helyet kapott a szociáldemokrata párt, 9 helyet foglalhatott el az alkotmányjogi demokrata párt (későbben nemzeti demokrata párt), szintén 9 hellyel rendelkezett az agrárpárt. A néppárt 4, az ócsehek 1 és a realisták úgyszintén 1 helyet kaptak a Nemzeti Bizottságban. A Bizottságban csak csehek voltak képviselve, szlovákok nem. A Nemzeti Bizottság de facto illegális szervként müködött, azonban az osztrák hatóságok a forradalmi helyzetre való tekintettel, ill. azért, hogy nem állt rendelkezésükre elegendő hatalmi erő, hogy likvidálhassa a forradalmi testületet, tolerálta a létét. V. ö. pl. Schelle Karel 2008, 22.
} 
serkentett. ${ }^{3}$ A konzervatív polgári pártok e politikáját legjobban Alois Rašín ${ }^{4}$ kifejező szavai illusztrálják: ,Ahol a nemzet sorsáról döntenek, ott nem ugranak a sötétbe”. A prágai polgári politikusok ugyanis koordinált akciót kívántak az emigráns politikusokkal, ill. Tomáš Garrigue Masaryk vezette párizsi Csehszlovák Nemzeti Tanáccsal, ${ }^{5}$ melynek fokozatosan egyik legkimagaslóbb személyisége Edvard Beneš lett, Csehszlovákia első külügyminisztere és 1935 -től második köztársasági elnöke. ${ }^{6}$ Ö saját maga a jól, törvényes és procedurális szempontból előkészített, az OsztrákMagyar Monarchiától való elválásnak volt a híve, és nem a váratlan forradalmi fordulatnak. Az emigráns politikusok ezen óvatossága már ekkor megalapozták az új állam politikai rendszerének az egyik alapjellemzőjét: a dolgokat egyszerüen nem szabad elsiettetni. ${ }^{7}$ Ekkor kevesen feltételezték, hogy a csehszlovák politikai rendszer ezen alapvonása, azaz a politikai folyamatok és a mérvadó kérdésékben való döntéshozatal nehézkessége lesz majd de facto két évtized múlva az oka az első köztársaság széthullásának, amelyet az évek folyamán, szinte figyelmen kívül hagyva a viharosan változó bel- és külpolitikai körülményeket, amelyekre csal későn képes reagálni, fokozatosan szépen lassan elösegített.

Azonban a helyzet Prágában lassan, de biztosan forradalmi fordulatba torkollott. A polgári párt képviselői, akik figyelmesen kísérték az események fejlődését Bécsben, s annak kétségbeesett igyekezetét megtartani a császár-királyi hadsereget a fronton, gyorsan észlelni kezdték, hogy elérkezett a monarchia végső pillanata. Erre már egyéb jelek is utaltak. Például a napokban enyhült a sajtócenzúra. ${ }^{8}$ A cseh lapok október 26án már leközölhették Beneš párizsi beszédét és egy nappal később, október 27 -én

\footnotetext{
${ }^{3}$ A Szocialista Tanács október 12-én úgy döntött, hogy az október 14-re összehívott demonstrációkat ki kell használni a szocilista állam kihirdetésére. A Szocialista Tanács a Nemzeti Bizottság tudta nélkül ebben az értelemben kibővítette a Nemzeti Bizottság által elkészített rezolúciót, kinyomtatta, mint röplapot, és ezt futárokkal vidékre azzal az instrukcióval juttatta el, hogy a szónokok ezt felolvasva hirdessék ki a csehszlovák államot. A Nemzeti Bizottságnak sikerült a végén a Szocialista Tanács akcióját a legtöbb helyen leállítani, azonban Písek és Kralupy nad Vltavou városokban a rezolúciót felolvasva, hivatkozva a Nemzeti Bizottság adta felhatalmazásra, kihirdették az önálló állam létrehozását, amely nagyobb demonstrációba torkollott. Ezek az elszigetelt események azonban kudarcba fulladtak, és bebörtönzésekkel végződtek. V. ö. Galandauer Jan 1988, 222-226., 310.; Rašín Alois 1994, 207-209.

${ }^{4}$ A Csehszlovák Köztársaság első pénzügyminisztere 1918 és 1919 között. Majd 1922 és 1923 között ismét a pénzügyminisztérium élén állt. A monarchia alkonyán a bécsi Birodalmi Tanács képviselője volt. Későbben a nemzeti demokrata párt egyik kulcsszemélyisége. 1915-ben a császár-királyi hatóságok letartóztatták, és a halálra ítélték, együtt Karel Kramář képviselővel, árulásért és kémkedésért. 1917-ben kegyelemben részesült. 1923-ban merénylet áldozata lett, amely következtében életét vesztette.

5 Az 1916-ban alakult párizsi Csehszlovák Nemzeti Tanácsot az egyes antanthatalmak fokozatosan hivatalosan elismerték, mint a csehszlovák nemzeti érdekek képviselőjét és mint a jövő csehszlovák független állam kormány alapját. A Csehszlovák Nemzeti Tanács vezéralakjai majd 1918 szeptember végén létrehozták az ideiglenes csehszlovák kormányt, amely csak háromtagú volt. A kormány élén Masaryk állt, aki még emellett pénzügyminiszter is volt. Tagjai lettek a kormánynak továbbá Edvard Beneš, mint külügyminiszter, és Rastislav Štefánik mint hadügyminiszter. Az ideiglenes kormány létrejötte hivatalosan 1918. október 14én volt bejelentve. A kormány legjelentősebb lépése az ún. washingtoni deklaráció kiadása volt október közepén, amely kinyilvánította a csehszlovák nemzet függetlenségét és előjelezte a csehszlovák állam létrejöttét október végén.

${ }^{6}$ Beneš Nagy Háború alatti tevékenységéről lásd Gulyás László 2008/a, 41-96.; Gulyás László 2008/b, 4384. Az emigráció programjának formálódásáról lásd Gulyás László 1996, 103-108. old.; Gulyás László 2000, 35-50.

${ }^{7}$ Čada Václav 1988, 88.

${ }^{8}$ A belügyminiszter a sajtócenzúrát véglegesen október 28 -án törölte. A döntés értelmében az osztrák belügyminisztérium tájékoztatta a tartományi politikai hivatalokat, hogy a kiadók nem kötelesek többé a kiadás előtt benyújtani az illető helyeknek a kötelező nyomtatványt. Erről a cseh sajtó még aznap a lapok esti kiadásaiban tájékoztatott. Lásd pl. Národní listy, Večerní vydání, 58. évf., 1918, 115. sz., október 28., 1. old., Preventivni cenzura zrušena.
} 
megjelenhetett a sajtóban Masaryk képe is. Sőt a Národní listy október 27-i kiadásának vezércikke címe „Az előest” volt, s ennek az első mondata így kecsegtette az olvasók reményeit: „,Már két lábakkal állunk a forradalmi talajon, az omladozó épületek porát lélegezzük és a Jordán utolsó dombjait lépjük át, amely mögött a fiatal szabadság ígéret földje fekszik." " Bár a mérvadó cseh pártok politikai képviselői Prágában még október 28-a előestéjén, sőt még október 28-án délelőtt sem értesültek az olaszok végzetes ellentámadásáról a Piave folyó balpartján az Osztrák-Magyar monarchia hadserege ellen, sőt arról sem volt még tudomásuk, hogy ennek hatására Bécsben a Koronatanács október 27-i esti ülésén felhatalmazta ifj. Andrássy Gyula gróf külügyminisztert, hogy az Amerikai Egyesült Államok elnöke révén fegyverszüneti ajánlatottal szólítsa fel az antant államokat, reggel október 28-án közös tanácskozásukon úgy döntöttek, hogy megteszik a szükséges elölépéseket az államhatalom átvételére. A hazai politikai színtér élvonalbeli politikusok tanácskozása az agrárpárt végrehajtó bizottságának elnöke, Antonín Švehla ${ }^{10}$ jelenlétében zajlott le. Ö ez időben helyettesítette Karel Kramářrt, ${ }^{11}$ a Nemzeti Bizottság elnökét, aki ekkor Genfbe utazott érdemleges tárgyalásokra a párizsi Csehszlovák Nemzeti Tanács tagjaival. Az említett mérvadó október 28-kai reggeli tanácskozás további résztvevői Alois Rašín, František Soukup ${ }^{12}$ és Jiří Stř́ibrný ${ }^{13}$ voltak, akik kilenc óra előtt találkoztak Švehla irodájában a belvárosi Havlíček téren. ${ }^{14}$ A megbeszélés fő szereplője és egyben a legaktívabb szereplője már Alois Rašín volt. Rašín ismertette a jelenlévőket az éjszaka folyamán a Bécsben tartózkodó Vlastimil Tusarral $^{15}$ folytatott telefonbeszélgetéséröl a bécsi politikai helyzetről, amely arra utalt, hogy a Monarchia véglegesen az összeomlás kapujába érkezik. A tanácskozás rövid volt és a jelenlévők abban állapodtak meg, hogy amint megérkezik Prágába híre a Monarchia kapitulációjáról, a Nemzeti Bizottság rögtön átveszi az országban a teljes hatalmat. A további események lefolyása arra utal, hogy a Nemzeti Bizottság vezéralakjainak ezzel kapcsolatban az volt a fö célja, hogy a hatalomátvétel minél

\footnotetext{
${ }^{9}$ Národní listy, 58. évf., 1918, 116. sz., október 27., 1. old., V předvečer.

${ }^{10}$ Antonín Švehla a húszas évek legjelentősebb politikusa volt Csehszlovákiában. Hosszú évek során ő volt az agrárpárt elnöke, amely posztot 1909 és 1933 töltötte be. Az agrárpárt az ő vezetése alatt lett az első köztársaság legjelentősebb politikai pártja. Két alkalommal miniszterelnök is volt, elöször 1922 és 1926 között. Rövid szünet után még 1926-ban újból miniszterelnök lett. Az ő kormányzása alatt alakult meg Csehszlovákia első jobboldali kormánya, amelybe hajlandó volt belépni a csehszlovák kisebbségi magyarok második parlamenti pártja is, a Magyar Nemzeti Párt, amely a második parlamenti választások után az aktivizmussal kacérkodott. Az újonnan megalakult kormány lett az állam első nemzetiségi kormánya, amelyben a németeket az aktivista német agrárpárt és a német keresztényszocialistapárt képviselte. Ettől kezdve mindegyik csehszlovák kormány nemzetiségi kormány volt, mivel mindegyik kormányban voltak németpárti miniszterek. Az 1918. július 13-án megalakult, ill. újjáalakult Nemzeti Bizottság elnökhelyettese lett.

${ }^{11}$ A háború alatti cseh politikai erők legtekintélyesebb alakja. 1918. november 14-én Karel Kramář lett a Csehszlovák Köztársaság első miniszterelnöke. A kormány élén 1919. július 8-ig állt. 1919 márciusában Csehszlovák Nemzeti Demokrácia néven pártot alapított, amelynek élén egészen 1934-ig állt, amikor a párt beolvadt a nacionalista Nemzeti Egység Pártjába.

${ }^{12}$ A szociáldemokrata párt jelentős személyisége, a bécsi Birodalmi Tanács képviselője. Az első hivatalos csehszlovák kormányban ő foglalta el az igazságügyi miniszteri posztot. A Nemzeti Bizottság ügyvivője volt. ${ }^{13}$ A szocialista párt „,második embere”, a bécsi Birodalmi Tanács képviselője. Az első csehszlovák kormányban ő vezette a posta és távirodai minisztériumot. 1926-ban kizárták a pártból és Nemzeti Liga néven nyílt fasiszta pártot szervezett, amely majd 1934-ban beolvadt a Nemzeti Egység Pártjába.

${ }^{14}$ Ma Senovážné náměstí, amely nem messze van a föpályaudvartól és a Vencel tértől.

${ }^{15}$ A Nemzeti Bizottság nem hivatalos képviselője Bécsben. Mint a Birodalmi Gyülés Képviselöházának elnöke kapcsolatban állt a bécsi kormánnyal. 1919. júl. 8.-1920. szept. 15. között ö lett a második csehszlovák miniszterelnök Karel Kramář után.
} 
simábban történjen meg. Az új állam alkotói erőszakos megrázkódtatás nélküli államfordulatban, ill. rendezett, felölröl és nem alulról jövö, veszélyes tömegeket kihasználó forradalomban gondolkodtak, amely nem csúszik át egy radikális szociális forradalomba, amely gyökeresen megváltoztatná a hagyományos társadalmi rendet és egy radikális társadalmi berendezkedéshez vezetne. A hatalomátvételének garanciáját az általános zavar és a kapitulációt követő osztrák hatalom bénultsága képezte. ${ }^{16}$

Október 28-a váratlan forgatókönyve, amelynek végén egy új állam születése volt, elkezdett íródni. Az ún. október 28 -a embereinek ${ }^{17}$ optimizmusát az időjárás is növelte. Prága szép napos, bár már hideg őszies napra ébredezett. Addig, ameddig már a Nemzeti Bizottság vezető konzervatív beállítottságú személyiségei is egyre inkább döbbentek rá a pillanat sorsdöntő jellégére, „,most vagy soha”, addig az osztrák hatalom a helyzet látszólagos nyugalmával dédelgette magát. Hiszen Max Julius von Coudenhove gróf, prágai császár-királyi helytartó elhagyta a Ferenc József pályaudvarról (ma Wilson pályaudvar) induló hétórai bécsi gyorssal Prágát, hogy Bécsben személyesen megismerhesse az új, Heinrich Lammasch professzor vezette kormány szándékát. Lammasch miniszterelnök még az utolsó pillanatban menteni akarta a Közép-Európai nemzetek közös államát föderatív alapon, amelyet magáévá tettek volna nemcsak az osztrák forradalmi erők, akik már október 21-e óta

\footnotetext{
${ }^{16}$ Čada Václav 1988, 37-42.; Rašín Alois 1994, 212-213.; Werstadt Jaroslav 1936, 28.; Národní listy, Večerní vydání, 58. évf., 1918, 114. sz., október 26. (esti kiadás), 2. old., Zahraniční ministr dr. E. Beneš československému lidu és Denní zprávy, Národní listy, 58. évf., 1918, 116. sz., október 27., 1. old., Tomáš Garrigue Masaryk. A Nemzeti Bizottság elnökség tagjai - Kramář és Rašín jelenlétében - október 25-én megegyeztek Bécsben abban, hogy a Nemzeti Bizottság a császár-királyi kormánnyal nem fog tárgyalni, ill., hogy nem hajlandó segíteni a bécsi kormánynak megtartani a fegyelmet az olaszországi harctéren harcoló katonai alakulatoknál, hanem mindent afelé fog iránytani, hogy Ausztria mielöbb kapituláljon. A fegyverletételt tekintette előfeltételnek az esteleges tárgyalásoknak a kormány és a Nemzeti Bizottság között. Ezen megbeszélés értelmében Tusar október 27-én visszautasította az osztrák fôparancsnokság azon kérelmét, hogy a Birodalmi Tanács cseh képviselöi utazzanak le a csatatérre, és hassanak a cseh katonákra, hogy még egy bizonyos ideig próbálják tartani a frontot, legalább addig, még nem sikerül hazahozni a milliárdokba kerülö hadianyagot. Közben a föparancsnokság beismerte, hogy nagyon sürgős a kérdés, hiszen nem napokról, hanem órákról van szó, azaz sürgette a képviselők rögtöni leutazását a frontra, mert a hadsereg bomlása már nagyon magas stádiumban volt. Tusar október 27-én este Rašínt elöször nyolc órakor hívta, majd még egyszer éjszaka tizenegy órakor, amikor Rašínt röviden csak arról értesítette, hogy a föparancsnokság a végén már nem jelentkezett, aminek révén Tusar arra a következtetésre jutott, hogy a császári hatalomnak sikerülhetett mégiscsak megszilárdítani a katonák morális helyzetét a fronton. Rašín ezt azonban nem így értelmezte. Az ő véleménye szerint ez éppen bizonyítéka volt annak, hogy Bécs véglegesen felismerhette, hogy a helyzet már egyáltalán nem menthető. Rašín Alois 1994, 211-213.

${ }^{17}$ Október 28-a embereinek nevezzük azokat a cseh politikusokat, akik ezen a napon részt vettek Prágában az új állam kikiáltásában, az említett Rašín, Švehla, Soukup és Stříbrný mellett még a szlovák Vavro Šrobárt ezek közé soroljuk. Šrobár az nap teljesen véletlenül utazott Prágába (a prágai útja eredeti fó célja az volt, hogy megtudja, mi újság Prágában), így ő is bele tudott közvetlenül kapcsolódni a váratlan politikai eseményekbe. A prágai Állami pályaudvaron (ma Masaryk pályaudvar) pár perccel tíz óra után szállt ki a vonatból, körülbelül abban az időben, amikor a Vencel téren az első emberek kezdtek csoportosulni az Andrássy-jegyzék hírére. Érdekességként megemlítendő, hogy Šrobárt éppen néhány nappal a prágai utazása előtt engedték Magyarországon szabadlábra, Wekerle Sándor miniszterelnök közbelépésének köszönhetően. 1918 tavaszán ugyanis Cegléden internálták, a szociáldemokrácia liptószentmiklósi május 1-jei gyülekezetén elhangzott beszéde miatt. Šrobár nagy támogatója volt a csehszlovakizmusnak, aminek köszönhetően ő lett az első, Szlovákia irányításával megbízott teljhatalmú minisztere. Emellett majd, a köztársaság első éveiben, egyéb miniszteri posztokat is betöltött. Az erős csehszlovakizmusa miatt nagyon gyorsan szembekerült a többi vezető szlovák politikustársaival az 1918 előtti időkböl, akik fokozatosan bírálni kezdték a létrejött csehszlovák állam centralizmusát. Annak ellenére, hogy 1922-től már nem volt tagja a kormánynak, továbbra is tekintélyes személynek számított a szlovák közéletben. A második világháború idején nyolcvanévesen bekapcsolódott a Szlovák nemzeti felkelésbe, a Szlovák Nemzeti Tanács társelnöke lett, sőt egy rövid ideig a Gottwald-kormány minisztere is volt az 1948-as kommunista puccs után. Čada Václav 1988, 45-46.
} 
ragaszkodtak az önálló Német Ausztriához, ${ }^{18}$ hanem a többi népek forradalmi szervei is. A helytartó nyugodtan hagyta maga mögött a Cseh Királyság fővárosát, hiszen a helyzet Prágában nyugodt volt, és még látszata sem volt annak, hogy forradalmi események uralják majd a nyugodtnak és napos napnak ígérkező hétfői napot, október 28-át. ${ }^{19}$

A hatalomátvétel elökészítésének első lépése a Háború Gabonahivatal, azaz az Ellátási Hivatal átvétele volt a Nemzeti Bizottság által. A Vencel tér melletti híres Lucerna Palotában ${ }^{20}$ székelő hivatalt a Nemzeti Bizottság nevében Švehla és Soukup vették át közvetlenül a fentvázolt reggeli tanácskozás után. A Gabonahivatal átvétele simán történt meg, hiszen a hivatal irányítói úgy értelmezték az eseményeket, hogy a Nemzeti Bizottság képviselői a cseh tartományok új vezetőiként cselekszenek, s cselekedetük nem jelenti az Osztrák-Magyar Monarchia egységének a megtagadását. Rašín eközben az Opletal utcai Národní listy szerkesztőségében ${ }^{21}$ személyesen találkozott Josef Scheinerrel, a Sokol tornaegylet elnökéjével. Scheiner itt Rašínnak személyesen megismételte, hogy a Sokol tagjaiból álló őrsök készen állnak biztosítani a szükség esetén a rendet az utcákon, amiröl Rašínt még reggel hat órakor értesítette telefonon. Rašín, aki a Tusarral való első telefonbeszélgetés után este október 27-én rögtön tudatosította a helyzet komolyságát, ugyanis rögtön felhívta Scheinert és arra hivatkozva, hogy véleménye szerint Ausztria kapitulá-

ciója már csak órák kérdése, felkérte, hogy másnapra tegyen meg minden előkészületet abban az irányban, hogy a Sokol tagjai rögtön pótolhatni tudják a katonaságot a rend fenntartása végett, ha az megtagadná az együttmúködést a Nemzeti Tanáccsal. ${ }^{22}$

Miközben a Nemzeti Bizottság képviselői készültek a hatalom átvételre, s nekifogtak az első előlépesek megvalósításához, a prágai lapokba beérkezett a hír az Andrássy-jegyzékről, bár még félhivatalos formában. Rašín visszaemlékezései szerint a Národní listy szerkesztősége már negyed kilenckor értesült a jegyzékről a lap bécsi szerkesztőségétől. A császár-királyi táviroda hivatalos jelentése az Andrássy-jegyzékről fél tizenegy körül futott be Prágába. A végzetes lavinát népmegmozdulás formájában Prága utcáin az Andrássy-jegyzék azon passzusa eredményezte, amely hivatkozott az amerikai elnök utolsó, október 18-iki jegyzékére. Ebben az amerikai elnök utalt az Osztrák-Magyar Monarchia népeinek önrendelkezési jogaira, különösképpen a csehszlovákok és délszlávok esetében. Ezzel a „,dezinformációval” indult el Prágában a forradalmi hullám. A fö lapok - České slovo és Národní politika - székhelyépületein lévő faliújságjain, amelyeken főképpen a harctéri eseményekről jelentek meg permanensen

\footnotetext{
${ }^{18}$ 1918. október 21-én a bécsi Birodalmi Tanács németajkú képviselői egybegyültek, Ideiglenes Nemzetgyülésnek nyilvánították magukat és kihirdették az önálló Német Ausztriát, amelyet nemcsak a szük értelemeben vett Ausztriának kellett képeznie, hanem a cseh tartomány német lakta vidékek (Szudéta vidék) és nyelvszigetek is az új osztrák állam kötelékeibe tartoztak volna. A csehországi németek a Szudéta vidéken Csehszlovákia kikiáltása után is ragaszkodtak Ausztriához és létrehoztak négy tartományt: Deutschböhmen, Sudetenland, Böhmerwaldgau és Deutschsüdmähren. Ezek a tartományok ellenezték bekebelezésüket Csehszlová-

kiába és Bécs fennhatóságát voltak csak hajlandóak elismerni. Az év végéig ezeket a területeket a csehszlovák katonaság fokozatosan Csehszlovákiához csatolta.

${ }^{19}$ Čada Václav 1988, 41.

${ }^{20}$ A híres Lucerna palota a Štěpánská és a Vodičkova u. között található, pár tíz méterre a Vencel tértől. A palota további érdekessége az, hogy a kivitelezője Vácslav Havel volt, aki Václav Havel, az utolsó csehszlovák köztársasági elnök, ill. a Cseh Köztársaság első elnök nagyapája volt.

${ }^{21}$ A lap szerkesztőségének székhelye csak néhány tíz méterre volt található a Vencel tértől. Az épületet, amelyben a Národní listy szerkesztősége székelt, 2013-ban bontották le.

22 Čada Václav 1988, 42.; Rašín Alois 1994, 213.
} 
tudósítások, október 28-ka délelőtt csupán nagybetüs felirat jelent meg: „Fegyverszünet”. A lapok faliújságjai előtt egyre többen gyülekeztek, s a hír Ausztria „kapitulációjáról” gyorsan terjedt Prága belváros utcáin. A népi manifesztációs tömeg a Vencel tér felső részében alakult ki, ahol a Národni politika szerkesztősége székelt. A tömeg hangulatát egyben fokozták a szerkesztőség épületére kitüzött nemzeti piros-fehér zászlók is, amelyek tovább bátorították az egyre sürübb tömeget, ill. arra hívták fel messzire a figyelmet a téren tartózkodó embereknek, hogy valami igazából nagy dolgok történnek. Ennek köszönhetően több és több nép érkezett a szerkesztőség épületéhez. Pár órán belül a Vencel tér többi épületein is megjelentek a cseh nemzeti lobogók. A tér nemzeti lobókkal való kidíszítésének a tetőpontját a Vencel tér alsó részében található Zlatá husa (Arany liba; a szálloda ma is áll) előtt álló híres „szláv hársfa” (a csehek nemzeti fája) képezte, amelyet virágokkal, pántlikákkal és trikolórral leptek el, és a tetejére amerikai zászlót helyeztek el, köszönetet fejezve ki ezzel az amerikai elnöknek Woodrow Wilsonnak. A piros-fehér szín lett a nap folyamán ura az egész Prága belvárosának. Ezt a prágai német liberális sajtó legbefolyásosabb lapjának, a Prager Tagblatt összefoglaló napijelentésének címe is világosan tükrözi: „Das weiss-rote Prag”. A nemzeti zászlók hamar a villamosokon is megjelentek, amelyek ezen felül díszítve lettek sebtében készített táblákkal, amelyek éltették az amerikai elnököt. A Vencel téren összegyült és állandóan gyarapodó tömeg spontánul, a cseh himnuszt énekelve, manifesztációs menetbe ment át, és az ünneplö nép ellepte Prága belvárosát, miközben az államügyészég és a helytartóság az ellen tiltakozott a lapoknál, hogy téves információt híresztelnek, hiszen az Andrássyjegyzék nem más, mint csak tárgyalási alap megfogalmazása az antanthatalmak iránt. A folyamat már megállíthatatlan volt, tizenkettő óra után az emberek csoportosan hagyták el munkahelyüket és gyülekeztek a Vencel téren. Prága belvárosa mindkét tere, a Vencel tér és a történelmi Óvárosi tér (Staroměstské náměstí), s ezeket a tereket összekötő utak megteltek több tízezres tömeggel. ${ }^{23}$

Körülbelül fél tizenegykor összeült a Nemzeti Bizottság elnöksége az Obecní dům-ban (Prager Gemeindehaus), Prága legismertebb szecessziós reprezentatív épületében, amely nem messze van a történelmi Óvárosi tértől, a mai Köztársaság téren, a Lőportorony mellett. Az eseményeket Švehla, Rašín, Stř́ibrný vitatták meg, majd társult hozzájuk Josef Scheiner, a Sokol tornaegylet elnöke. A jelenlévők elemezték a fennállt helyzetet, a tömegek spontán felvonulását. A Nemzeti Bizottság elnökségének tagjai világosan észlelték a pillanat erejét, a nemzet megmozdulását, amely már messzemenő reakciót követelt. Rövid időn belül tudatosították, hogy megérkezett a régóta várt és óhajtott pillanat. Nem volt sok idő töprengeni, keresni az összeköttetést a párizsi Csehszlovák Nemzeti Tanáccsal és a Genfben tartózkodó Nemzeti Bizottság elnökével. ${ }^{24}$ Dönteni kellett, hiszen abban is tisztában voltak az urak, hogy a

\footnotetext{
${ }^{23}$ Čada Václav 1988, 43-44.; Rašín Alois 1994, 214.; Werstadt Jaroslav 1936, 29.; Dorazil Otakar 1920, 24.; Národní politika, 36. évf., 1918, 250. sz., 1. old., Praha pozdravuje neodvislý československý stát! Prager Tagblatt, 43. évf., 1918, 251. sz., 3. old., Vom Tage. Das weiss-rote Prag.

${ }^{24}$ A császár-királyi hatalom már október vége felé olyannyira rezignált állaspontra helyezkedett, hogy útlevelet adott a Nemzeti Bizottság képviselőinek, hogy azok a semleges Svájcba utazhassanak és ott találkozhassanak a külföldi ellenállás, azaz a párizsi Csehszlovák Nemzeti Tanács tagjaival. Svájcba a Nemzeti Bizottság képviselői, Kramář élén, október 25-én este utazott Bécsböl, az ottani fentemlített közös tanácskozásokról. Az út fő célja a két forradalmi testület programjának egyesítése volt. A Csehszlovák Nemzeti Tanács delegációját Edvard Beneš vezette. A tárgyalások Genfben zajlottak le, a Hotel Des beaux Rivages, a város legpazarabb szállodájában, amelyben több alkalommal Ferenc József Felesége, Erzsébet királyné is többször megszállt, és amely előtti utcán majd meggyilkolták. A tanácskozások október 28. és 31. között folytak le, s eredményüket három írásban tett nyilatkozat rögzítette. Ezekben a Nemzeti Bizottság kinyilvánította köszönetét a csehszlovák ellenállás külföldi képviselőinek, ill. elismerte az október 14-én kihirdetett ideiglenes kormányt és azonosult minden idáig tett
} 
tömegmegmozdulás igazi forradalomba torkolhat és a hivatalos fegyveres erők is közbe léphetnek. A döntés gyorsan született: Ki kell hirdetni az önálló csehszlovák államot, át kell venni a teljhatalmat az országban, megtenni mindent, hogy a császár-királyi fegyveres erők ne vonuljanak ki az utcára, értesíteni kell a vidéket és végrehajtani a hatalomváltást Brünnben és Olmützben, tehát az ország többi központjaiban. ${ }^{25}$

A tanácskozás után mind a négy említett politikus beült az autóba és átment a Kisoldalra (Malá Strana), a Helytartó palotájába, hogy személyesen tájékoztassák a beállt helyzetről a helytartót. Csak itt vettek tudomást arról, hogy a helytartó reggel elutazott Bécsbe. A Nemzeti Bizottság képviselöit viszont fogadta a cseh tartomány második legmagasabb közigazgatási hivatalnok, a helytartó helyettese, tartományi alelnök Jan Kosina. A Namzeti Bizottság nevében Švehla tájékoztatta a helytartóhelyettest, hogy a Nemzeti Bizottság, mint a nép akaratának a végrehajtója átvette a hatalmat az újonnan kihirdetett csehszlovák államban, ill. hogy átvette a Gabonahivatalt, amely hivatalnokai felesküdtek a Nemzeti Bizottságra, és hogy ez alkalommal készek átvenni a civil közigazgatást is az országban, amely ez idáig a helytartóság kezében volt. Švehla biztosította a tartományi alelnököt, hogy a Nemzeti Bizottság fő célja fenntartani a rendet és hogy az érvényben lévő törvények és rendeletek továbbra is hatályukban maradnak. Kosina higgadtan tudomásul vette az információkat, s ezeket rögtön továbbította is Bécsbe. A Helytaróságból az államalkotók átmentek a közeli Cseh Királyság Országgyülés épületébe, hogy értesítsék a beállt helyzetről az itt székelő tartományi közigazgatás elnökét is, gróf Adalbert Schönbornt. Közben kikérték maguknak, hogy engedjék be a tartományi országgyülés tárgyalótermébe, arra való tekintettel, hogy az épületben hamarosan összeül a csehszlovák állam Nemzetgyülése, ezért meg akarnak győződni arról, hogy a terem készen áll e történelmi pillanatra. Az új állam képviselöi ez alkalommal megdöbbenve tapasztalták, hogy a tárgyalótermet élelmiszer raktárként használták. A terem tele volt liszteszsákokkal, burgonyával, cukordobozokkal és konzervekkel. Az október 28-a emberei megparancsolták Schönborn grófnak, hogy a termet rögtön helyezzék eredeti állapotba. ${ }^{26}$

A négy szóban forgó államalkotó politikus ezek után elhagyta a Kisoldalt és átautózott vissza a Moldva folyó jobbpartjára, a város központjába, a Vencel térre. Az átutazás közben meglepően tapasztalták a forradalmi hangulatot Prága utcáin. Az egész város a lábain állt, mindenütt csehszínü piros-fehér zászlók lebegtek, a rendőrőrök sapkáit már szláv trikolór díszítette. A nép rajongot, énekelt és nekiállt átfestegetni a német feliratokat és likvidálni az üveges németnyelvü hirdetőtáblákat. A történelem alkotói egyben tisztában voltak azzal, hogy mielőbbi intézkedéseket kell tenni az irányban, hogy a néptömegek energiája kontroll alatt maradjon, ill. hogy a helyzet ne nőjön át radikális, szociális forradalomba. Ezért úgy döntöttek, hogy a nép spontán reakciójának semlegesítésére zenekarokat vezényeltetnek ki az utcákra, hogy a nép levezethesse a feszült hangulatot nemzeti dalok éneklésével. Ezirányban rögtön felkérték a Városi Hivatalt, hogy tegyen megfelelő intézkedéseket. Ennek a lépésnek

\footnotetext{
döntésével és politikájával, valamint deklarálta a nemzet végleges elválását a Habsburg dinasztiától. Továbbá mindkét forradalmi testület megállapodott Csehszlovákia államformájában, tehát abban, hogy az új állam köztársaság lesz. Az október 14-én hivatalosan kihirdetett háromtagú ideiglenes kormány elismerést nyert a Nemzeti Bizottságtól, amely egyetértett azzal is, hogy az ideiglenes kormány a jövendő kormány alapját képezi majd. A Nemzeti Tanács és a Nemzeti Bizottság delegációi egyben megállapodtak abban, hogy Csehszlovákia első köztársasági elnöke Tomáš Garrigue Masaryk és első miniszterelnöke Karel Kramáŕ lesz. A genfi tárgyalásokhoz lásd: Čada Václav 1988, 76-88; Galandaeur Jan 1988, 227-231.

${ }_{25}^{25}$ Cada Václav 1988, 47-48; Werstadt Jaroslav 1936, 32-34.; Rašín Alois 1994, 214.

${ }^{26}$ Čada Václav 1988, 48-50; Werstadt Jaroslav 1936, 34.; Rašín Alois 1994, 214.
} 
köszönhetően sikerült az október 28-ai népmegmozdulást végérvényesen utcai ünnepségek szintén megtartani. Egyben sikerült visszatartani a császár-királyi haderőt is, amely nem lépet fel a forradalmi helyzet ellen. Arra való tekintettel, hogy Prágában abban az időben több ezer magyar katona állomásozott, az aggodalmak nem voltak lényegtelenek. Még a forradalom kitörése előtt a Nemzeti Bizottság és a császár-királyi hadsereg között egyesség jött étre, hogy a katonák nem avatkoznak be az események alakulásába, ha nem lesz megbolygatva a nyugalom és a rend az utcákon. A független csehszlovák állam kikiáltása napján, október 28-án este meg sikerült a Nemzeti Bizottságnak a császár-királyi haderő prágai képviselőjével kompromisszumos megegyezést kötni, amely értelmében mindkét fél kölcsönös együttmüködésre kötelezte magát a rend fenntartása érdekében és a Prágában állomásozó haderő parancsnoksága egyben elismerte a Nemzeti Bizottságot, mint a császár-királyi Helytartóságot felváltó központi hatalom hordozóját. ${ }^{27}$

Közvetlenül azelőtt, hogy a négy államalkotó a Vencel-térre ért, visszatért ide az ujjongó fö menet a Na př́kopy (Am Graben), Prága belváros egyik fő utcájáról, amely a középkori városfal előtti árok helyén alakult, és amely elválasztja az Ovárost (Staré Město) az Új Várostól (Nové město). Amikor a menet visszatért a Vencel tér felső részéhez, a Szent Vencel szoborhoz, a nép felismerte a tömegben Isidor Zahradník katolikus papot, agrárpárt képviselöjét, aki azok a kevés katolikus papok közé tartozott, akik nyíltan szót emelt a Habsburg monarchia ellen. Zahradník pap képviselőből lett az első „sztár”, hiszen ő szólhatott először az óriási tömeghez: „Felkeltünk a mi önállóságunk érdekében. Azt, amiröl a mi nagyapáink nem is álmodhattak, mi valósitjuk most meg és testesitjük meg tettekben. Mindörökre feltörtük azokat a bilincseket, amelyekben az áruló, idegen és amorális Habsburgok kínoztak... Szabadok vagyunk és a mi szabadságunkat senki sem veszi el, csak akkor, ha magunk lemondunk róla... ". ${ }^{28}$

Ekkor azonban érkeznek meg a Szent Vencel szoborhoz a Nemzeti Bizottság képviselői. Rašín, Soukup, Švehla és Stříbrný, akik először állnak az ünneplö tömeg elé és megerősítik azt, amit Zahradník mondott beszédében, tehát azt, hogy a csehszlovák nép kivívta a szabad csehszlovák államot, az önállóságot. A tömeg nagy éljenzés közepette a Nemzeti Bizottság tagjai ismét beülnek az autóba, amely a Vencel tér alsó része felé veszi az irányt. Nemsokára az autó ismét megáll, a Jindřišská és a Vodičkova utcák sarkán, a nyílt autó ülésére felállt Stř́ibrný, aki ismét a tömeghez szólalt: „A Nemzeti Bizottság bejelenti önöknek, hogy a szabad és független csehszlovák állam valóság lett”. Majd csatlakozik hozzá Soukup is, aki bejelenti, hogy: „A Nemzeti Bizottság, mint a nemzet akaratának végrehajtója áll önök elött, mint az önök kormánya... Ebben a szent pillanatban... a Nemzeti Bizottságnak csak egy kérése van önökhöz: Tartsátok be mindenütt a rendet és a nyugalmat! Egyetlen egy csehszlovák kéz sem emelkedjen fel semmilyen eröszakos tett végrehajtása véget...”. A Nemzeti Bizottság elnökségének tagjainak a Vencel-téren való felszólalásnak fő célja föképpen a rend megtartása volt, ezért nyomatékosan apelláltak a tömegekre, hogy mindenki ezen a pillanattól feltétlenül vesse alá magát a Nemzeti Bizottság rendelkezéseinek. ${ }^{29}$

Fél hat körül gyülekezni kezdtek a Nemzeti Bizottság tagjai az Obecní dům Gréger termében. Hat óra után felszólalt Antonín Švehla. Beszédében megállapította, hogy a Nemzeti Bizottság legitim testület a hatalomátvételéhez és az új szuverén állam jogainak

\footnotetext{
${ }^{27}$ Rašín Alois 1994, 214-216.; Klimek Antonín 2000, 19-20.; Dorazil Otakar 1920, 25.

${ }^{28}$ Čada Václav 1988, 51-52.

${ }^{29}$ Čada Václav 1988, 52.; Národní listy, Večerní vydání, 58. évf., 1918, 115. sz., 1. old., Národni výbor prejímá správu československého státu.
} 
gyakorlásához. Mindenki előtt nyilvánvaló volt, hogy az új állam kihirdetéséhez vezető lépesek már megtörténtek. A nép spontán, forradalmi fellépése beindította a folyamatot, amelyet nem lehetett figyelmen kívül hagyni. Ahhoz, hogy a Nemzeti Bizottság megtarthassa a forradalmi vezető testületének szerepét, a nap eseményei után szükséges volt hitelesíteni a nép követelte önálló állam kihirdetését. A Nemzeti Bizottság elnökségének ezen döntése után Rašín ragadta meg a szót. Rašín a jelenlévőknek felolvasta az önálló csehszlovák állam első törvényjavaslatát, amelyet a fent említett Tusarral való telefonbeszélgetés hatására fogalmazott meg az előző éjszaka folyamán. A törvényjavaslat horderejü rendelkezését a független csehszlovák állam kihirdetése jelentette. A törvénytervezet továbbá rendelkezett arról, hogy az államforma meghatározása a későbbi időkben fog megtörténni, éspedig egyetértésben a párizsi Csehszlovák Nemzeti Tanáccsal. A törvényjavaslat egyben biztosította a jogfolytonosságot, amikor megállapította, hogy az érvényben lévő jelen törvények továbbá is érvényben maradnak és a mindegyig meglévő hivatal továbbra is fennál és végzi ügykörét az illető törvényekkel és rendelkezésekkel összhangban. Az utolsó rendelkezésnek az volt a célja, hogy biztosítsa a közigazgatás további zavartalan müködését. A felterjesztett törvényjavaslat fölött nem bontakozott ki nagyobb vita és változatlanul el lett fogadva, amivel - ahogyan Rašín írja visszaemlékezéseiben - az államfordulat be lett fejezve. A Nemzeti Bizottság elnökségének tagjai abban egyeztek meg, hogy mindenféleképpen szükséges megtartani a forradalom „nemzeti” jellegét, távol tartani a forradalmat bármilyen radikális céloktól és a polgári rend megdöntésétől, ill. hogy szükséges megtartani a forradalmat a jogfolytonosság alapján, a meglévő társadalom berendezkedés megtartását. ${ }^{30}$

Október 28-án este tehát a Nemzeti Bizottság törvényhozó testületté változott. A tanácskozás a végén még elfogadott egy fontos kiáltványt, amelynek ezen a napon sokkal nagyobb jelentősége volt, mint az említett törvénynek, hiszen a második dokumentum az utcákon lévő és ünneplő tömegnek szólt. A kiáltvány óvva intett bármilyen erőszakos cselekményektől: , Csehszlovákok! Évszázados álmotok valósággá vált. A mai napon a csehszlovák állam belépett a világ független, liberális, kulturált országának sorába. A Nemzeti Bizottság az egész csehszlovák nép általi bizalommal felruházva, egyetlen törvényes és felelös szereplöként saját kezébe vette az államhatalmat. ... A nagy munka kezdetén a Nemzeti Bizottság, a mai naptól a kormányotok, meghagyja Nektek, hogy magatartásokot és örömötök legyen méltó e nagy pillanathoz. Felszabaditóink, Masaryk és Wilson nem csalódhatnak azon meggyözödésükben, hogy oly népnek vívták ki a szabadságot, amelyik képes saját magát kormányozni. Ne zavarjátok meg semmilyen tettel a mostani nagy pillanatot, senki ne kövessen el semmi olyat, ami árnyékot vethet a nemzet tiszta nevére. Mindannyian fenntartás nélkül óvjátok meg mindazt, ami másnak szent. A személyes szabadság és a magántulajdon sértetlen marad. "31

Közben délután a forradalom híre elkezdett fokozatosan terjedni a tartomány többi városaiba. Brünnben a prágai történtekről este hat órakor értesültek és másnap, október 29-én, Cseh- és Morvaország mindegyik régiója tudatában volt a történtekkel. Október

\footnotetext{
${ }^{30}$ Čada Václav 1988, 70-71; Werstadt Jaroslav 1936, 45-46.; Rašín Alois 1994, 216.; az említett csehszlovák állam első törvényéhez lásd a korabeli sajtót, pl. Národní listy, 58. évf., 1918, 117. sz., 1. old., Zákon vydaný Národním výborem dne 28. řijna 1918; a törvény magyar fordításához lásd Bencsik Péter 2016, 57.

${ }^{31}$ Schelle Karel 2008, 23.; Čada Václav 1988, 71-72; a Nemzeti Bizottság idézett kiáltványhoz lásd a korabeli sajtót, pl. Národní listy, 58. évf., 1918, 117. sz., 1. old., Lide československý!; a kiáltvány magyar fordításához lásd Bencsik Péter 2016, 57. old.
} 
31-ig Cseh- és Morvaország belső vidékén megtörtént a hatalomátvétel, a határmenti vidékeken, azaz a német lakta területeken csak fokozatosan, az év végéig tudta a Nemzeti Bizottság átvenni a hatalmat. A hatalomátvételnek első szakasza, azaz az október végi hatalomátvétel a tartomány belső részében gyorsan és simán történt, annak köszönhetően, hogy az osztrák államhatalom, tartva a forradalmi nép radikalizálódásától és szociális forradalom kitörésétől, akadálymentesen engedte át a pozícióját az újonnan született hatalom hordozóinak, az új államhatalom reprezentánsainak. A Nemzeti Bizottságnak sikerült a hatalométvétel közben féken tartani a néptömegeket is és megakadályozni, hogy a népmegmozdulás szociális forradalomba menjen át és a tervezett polgári állam helyett szocialista állam kikiáltása legyen az eredménye a népmegmozdulásnak, bár a Právo lidu szociáldemokrata lap szerkesztősége az épületjére kihelyezte október 28-án a következő feliratot helyezett ki: „Éljen a szocialista köztársaság!" A néptömegek forradalmiságának semlegesítésében nagy szerepe volt a Szocialista Tanácsnak, amely összhangban müködött a Nemzeti Bizottsággal. Október 28-án azzal a felkéréssel fordult „az összes csehszlovák munkáshoz", hogy maximálisan támogassa a Nemzeti Bizottságot és rendelkezéseit, kifejezve ezzel a Szocialista Tanács vitathatatlan alárendelését a Nemzeti Bizottságnak. $^{32}$

A csehszlovák állam 1918. október 28 -án ${ }^{33}$ véglegesen megszületett, ténnyé vált. Az új államhatalom az év végéig fokozatosan kiterjedt az egész országra, előbb Csehés Morvaországra, majd, bár sokkal nehezebben, Szlovákiára és Kárpátaljára is. 1919 tavaszán a Párizsi békekonferencián megállapították az új állam határait, amelyek véglegesen megerősítették azt a paradox tényt, hogy a többnemzetiségü OsztrákMagyar Monarchia végeredményében ugyanolyan többnemzetiségü államokkal lesz felváltva, mint amilyen maga az „utált” közös Monarchia volt. A csehek és a szlovákok csupán a lakosság két harmadát tették ki Csehszlovákiában. A 13 milliós országban a németek aránya majdnem elérte a $25 \%$-ot, a magyarok aránya megközelítette a $7 \%$-ot, azonban csak Szlovákiát tekintve majdnem elérte a 22\%-ot. Csehszlovákia erős többnemzetiségü jellegével az állam megálmodói tisztában voltak, hiszen tudták, hogy a csehek önmagukban csupán 51\%-os, a Szlovákok pedig csak 14\%-os arányban lesznek képviselve a megtervezett közös államban. Ezért az állam jogosultság egy egységes, mesterségesen megalapított államalkotó csehszlovák nemzet konstrukcióval okolták meg. Azonban nemcsak a nemzeti kisebbségekkel való együttélés, a közös cseh-szlovák együttélés is nemsokára lassan, de biztosan az államot a belsőkrízis felé irányította,

\footnotetext{
${ }^{32}$ Galandauer Jan 1988, 233-234; Dorazil Otakar 1920, 25.

${ }^{33}$ A jogi szempontot figyelembe véve azonban a mérvadó, föképpen korabeli szakirodalomban több, gyakran egymással ellentmondó véleménnyel találkozunk az önálló csehszlovák állam létrejöttének dátumával kapcsolatban, bár a szakmai jogi vitát manapság már lezártnak tekinthetjük, éspedig október 28-ika javára, amelyet maga Masaryk is elfogadott, mint az ország végleges megszületésének dátumát. Egyes korabeli jogi szakvélemények azonban megkérdőjelezték azt a felfogást, hogy jogi szempontból egy állam létrejöttéhez elég csupán az, hogy egy nemzet a saját területén nyilvánosan kihirdeti önállóságát, hivatkozva itt egy állam létrejöttének nemzetközi aspektusaira. Ezen vélemények képviselői azt vallották, hogy az állam létrejötte a többi állam elismeréséből ered. Azonban ebből a szempontból is eltértek az egyes vélemények, hiszen nem volt meg az egyezség abban, hogy melyik állam elismerésének van konstitucionális jellege Csehszlovákia létrejötte szempontjából. Egyesek szerint a csehszlovák állam akkor alakult meg hivatalosan, amikor hatályba léptek a békeszerződések. Egyéb szakvélemények szerint a csehszlovák állam már akkor létrejött, mikor az antant hatalmak elismerték a párizsi Csehszlovák Nemzeti Tanácsot, mint az ellenállás hivatalos orgánumát ideiglenes kormány formájában. Maga Karel Kramář, a Nemzeti Bizottság elnöke pedig Csehszlovákia megszületését 1918. november 14-ével határozta meg, amikor miniszterelnökként a Forradalmi Nemzetgyülés első ülésén kinyilvánította a Habsburgok trónfosztását. Schelle Karel 2008, 23-24.
} 
amely majd „társulva” a világválság hatásaival és a külpolitikai fejleményekkel elvezettek fokozatosan előbb a müncheni szerződéshez, majd az első bécsi döntéshez, s 1939 márciusában pedig a Csehszlovák állam tényleges likvidálásához.

\section{Felhasznált irodalom}

Bencsik Péter 2016, Csehszlovákia története dokumentumokba. Budapest: Napvilág. Čada Václav 1988, 28. ř́jen 1918. Skutečnost, sny a iluze. Mladá fronta: Naše vojsko. Praha.

Dorazil Otakar 1920, Naše revoluce. Obrazy z domácí a zahraniční politiky od počátku světové války až do prvého výročí českého převratu. Literární kroužek. Kyjov.

Galandaeuer Jan 1988, Vznik Československé republiky 1918. Programy projevy, perspektivy. Nakladatelství Svoboda: Naše vojsko. Praha.

Gulyás László 1996, Egy sikeres emigráció anatómiája. Edvard Benes 1914-1918. AETAS 1996/2-3. szám 103-108. old.

Gulyás László 2000, „Zúzzátok szét Ausztria-Magyarországot!” Avagy a MasarykBenes-féle csehszlovák emigráció érvrendszerének első szintézise. LIMES 2000/4. szám 35-50. old

Gulyás László 2008/a, Edvard Beneš. Közép-Európa koncepciók és a valóság. Máriabesnyő-Gödöllő: Attraktor Kiadó.

Gulyás László 2008/b, Beneš statesman or charlatan? The plans and the reality 19081948. Toronto-Buffalo: Corvinus Publishing.

Klimek Antonín 2000: Velké dějiny zemí Koruny české, XIII., 1918-1929. Paseka. Praha: Lytomyšl.

Národní listy 1918, 58. évf.

Národní politika 1918, 36. évf.

Prager Tageblatt 1918, 43 évf.

Rašín Alois 1994, Paměti Dr. Aloise Rašína. Z otcových zápisů sestavil Dr. Ladislav Rašín. Bonus A. Brno.

Schelle Karel 2008, Vznik Československé republiky 1918. K 90. výročí vzniku Československé republiky. Key Publishing Ostrava.

Werstadt Jaroslav 1936, Den osvobození. Pořadatelům oslav ke dni 28. října. Masarykův lidovýchovný ústav. Praha. 